\title{
Collaboration of Local Election Supervisors with Neighbourhood Association (Rukun Tetangga) to Make an Antimoney Politic Community Movement During the Pandemic Covid 19
}

\author{
Tatang Sudrajat* \\ Universitas Sangga Buana \\ Bandung, Indonesia \\ *id.tatangsudrajat@gmail.com
}

\author{
Umi Rahmawati \\ Universitas Baturaja \\ Ogan Komering Ulu, Indonesia \\ umir1964@gmail.com
}

\author{
Tinda Irawati \\ Universitas Jenderal Achmad Yani \\ Cimahi, Indonesia \\ tindaira@yahoo.co.id
}

\begin{abstract}
Controlling of all stages of the local election (pilkada) is a very decisive aspect for the success of its overall implementation. It is impossible for Election Supervisory Agency (Bawaslu) and its staff to carry out their controlling function optimally without the support and cooperation of other parties. Money politics is still a major problem that can degrade the quality of local elections. With the normative juridical research method, literature review and secondary data analysis, it is known that local elections are very meaningful for the implementation of local government through the selection of regional leaders. Controlling of all stages of regional head elections involving the Rukun Tetangga as a component of society is very important for the growth of the anti-money politics movement in society. The challenges and problems faced by election supervisors are getting bigger during the current Covid 19 pandemic. Collaboration between local election supervisors and Rukun Tetangga administrators is a strong partnership for the growth of the anti-money politics movement. This is a major contribution to the implementation of an increasingly quality local election.
\end{abstract}

Keywords—collaboration, supervisors, local election

\section{INTRODUCTION}

One of the areas of national development today is political development, particularly domestic politics. The purpose of political development is basically to realize an increasingly democratic political system, including in the implementation of regional governance. Among other things, this will start with the process of democratically elected regional leaders. In other words, there is a big challenge for all political stakeholders in the regions to hold democratic events at the local level in a higher quality. Therefore, direct elections for regional heads and deputy regional heads (Pilkada) which were held for the first time in Indonesia in 2005 are an important part of efforts to improve the quality of political and democratic life at the local level.

Pilkada stakeholders, especially the organizers of course understand very well the dynamics of the problems that arise with all the consequences. Based on tracing data from several regional elections in various regions in Indonesia, it appears that various obstacles, challenges, and problems always confront at every stage of its implementation. One of the problems that have arisen that has become part of the dynamics of regional elections is that money politics is still rife. This is certainly one of the defects in its implementation which at a macro level can reduce the meaning and quality of governance and democracy at the regional level.

Pilkada implementation in the context of political development is basically for the birth of regional government capability, which is supported by, among other things, regional leaders with integrity. Regional heads and deputies with such qualifications are the main factors as the basis for the realization of regional government functions that fully serve the public. In this context, the issuance of various state policies in the form of laws regulating elections and regional elections is essentially a public policy. That said, because the substance regulated in the law contains the content of the public interest in the form of the aspirations and hopes of citizens at the local level for the election of regional leaders as they expect. 
In this framework, the enactment of Law Number 7 of 2017 concerning Elections and Law Number 1 of 2015 concerning Stipulation of Perpu Number 1 of 2014 concerning the Election of Governors, Regents and Mayors into Law (which has undergone two changes) is an important part. from efforts to improve the quality of democracy and political life more broadly at the local level. These two regulations provide a very strong juridical basis for the implementation of the duties and functions of the election supervisor, namely the Election Supervisory Body (Bawaslu) and its staff to the lowest levels.

Bawaslu in accordance with Article 1 number 17 of Law Number 7 of 2017 [1], which is tasked with overseeing the implementation of elections, along with all slag lines down to the lowest level, has a strategic role to contribute to realizing these expectations. For this reason, support from community components, especially the Rukun Tetangga (Rukun Tetangga) management, is a great asset for efforts to implement more effective supervision. In turn, this will become the main support for the implementation of an increasingly quality regional election.

This study aims to discuss the importance of pilkada and democracy, the role of pilkada supervision, the anti-money political movement, and the collaboration of pilkada supervisors with Rukun Tetangga in realizing an anti-political money movement for quality pilkada.

\section{RESEARCH METHODS}

The study used a combination of normative juridical methods, library research and secondary data analysis. The focus of attention of researchers is directed at various laws and regulations at various levels of government regarding pilkada, legal products for pilkada supervisors in the form of Bawaslu regulations on election supervision and various literature in the form of books, journals and other sources of scientific writing on the theme of election supervision.

\section{RESULT AND DISCUSSION}

\section{A. Election and Democracy}

The direct importance of the pilkada by the people is built on a number of arguments. According to Haris, some of them are the direct regional elections which are expected to improve the quality of sovereignty and people's participation because the people can directly determine and elect the candidate pairs that are considered the best in fighting for their interests; and is expected to minimize money politics that generally occur transactional when elections are held by DPRD [2].

The significance of the pilkada, especially directly by the people, cannot be separated from the discussion about the meaning of democracy. We all seem to understand very well that the root of the words "demos" and "cratos" for democracy actually mean very broad and have a universalistic dimension. Not only does it mean "people who rule / rule", but it has also penetrated various dimensions of human life in various parts of the world [3]. There is hardly a single segment of life that does not involve itself or be involved in realizing efforts to bring about democratization in various areas of life. Borrowing Huntington's term, in human life on earth what he calls a wave of democratization has taken place [4].

Academic discourse on democracy has been widely carried out by political science experts or researchers to explain what and how the democratic governmental order is. This vocabulary is not only related to the values that are important for humans in navigating their lives, but also related to the procedures or mechanisms of how humans attempt to realize their ideals at various levels of their life as social beings, including in state life. Although there is no single agreement among the students about the meaning of democracy because each has different perspectives, it is very clear when one looks at the root of the words demos and cratos. In other words, this means that democracy is a concept that wants to place humans according to their dignity.

Michael said that there are several key elements of democracy, namely representation [5]. With an expression that is not much different, Henry B. Mayo mentions several democratic values, including organizing a change of leadership regularly [6]. In a language that is not much different, the criteria for democracy according to Dahl include that officials are elected in elections which are held honestly and freely, and practically all adults have the right to be elected as an official in government [7]. In connection with the characteristics of the state, Michael also pointed out the existence of several characteristics of democratic government, including the institutionalization of the process of government -in which functions are delineated, responsibilities are defined, and the mechanisms for change, including elections, are prescribed [5]. In line with that, Budiardjo stated the essential characteristics of a democratic state, including free elections [8].

Referring to the views of these experts, that elections are one of the main characteristics of a democracy. In other words, it is impossible for a country to be called democratic if there has never been an election which of course must run freely, honestly, and fairly. If we follow Abraham Lincoln's view of democracy, government from the people can be interpreted as the people who are the source of sovereignty, power, mandate, or authority in managing the country. For this reason, the momentum deemed appropriate for the people to make their political choices is none other than elections.

Elections (election, general election) in democratic practice in various parts of the world are related to the existence of political parties. Blondel stated that parties are the main link between people and government in the contemporary world. Elections are the key mechanism of this link: they are the only way in which the bulk of the population can express its support for a party rather than another [9]. According to Ball, elections are the means by which the people choose and exercise some degree of control over their representatives [10]. He further argued, in many political systems, the role of elections is A form of political communication between government and the governed; A means by which political decision makers become 
sensitive to the electorates political demands, and turn are in a position to educate the electorate on important political issue; Are primarily a means of legitimizing the right of the rulers to govern [10].

In the context of regional governance, this election is in accordance with the implementation of regional head and deputy regional head elections (pilkada or post-conflict local elections). This has been going on since 2005 in accordance with the expiration of the term of office of each regional head, both for the provincial, district and city levels up to the beginning of 2014. After the enactment of Government Regulation in Lieu of Law Number 1 of 2014 concerning Governor Election, the Regent, and Mayor [11] since October 2, 2014, is regulated in Article 201 concerning simultaneous voting in the election for governors, regents and mayors. This moment then gave rise to the term Pilkada simultaneously. In the first stage, the voting took place on 9 December 2015, the simultaneous regional elections took place in 269 regions (provinces, districts, and cities) in Indonesia. In subsequent developments, in accordance with the provisions of Article 25 of Law Number 10 of 2004 concerning the Formation of Laws and Regulations, the Government Regulation in Lieu of Law Number 1 of 2014 then became Law Number 1 of 2015.

At present, simultaneous regional elections will be held on Wednesday, December 9, 2020 in 270 provinces, regencies, and cities. Even though until now there are still disagreements among observers about the predicate of a pilkada as an election or not, one thing that is certain is that the holding of elections for governors, regents and mayors and their deputies is essentially a democratic event at the local level. It is through local political events in various regions that the people as the legal holders of sovereignty in this country as stipulated in the provisions of Article 1 Paragraph (2) and Article 18 Paragraph 4 of the 1945 Constitution will demonstrate their power or authority to elect leaders in their respective regions.

\section{B. The Role of Election Oversight}

In administrative and management scientific terminology it is well known that supervision is one of the organic functions of administration / management which greatly determines the achievement of the stated organizational goals. This supervisory function is carried out to identify and ensure that the implementation of organizational activities is in accordance with established standards, policies, plans or programs. In this connection, Siagian argues that supervision is the process of observing the implementation of all organizational activities to ensure that all work being carried out goes according to a predetermined plan [12]. Within the framework of the political system and state administration, it is clear that the pilkada is a national agenda that requires certainty for its success.

In this regard, the duties and authorities of Regency / Municipal Bawaslu as stipulated in Article 30 in supervising the stages of organizing the Pilkada are truly very significant as part of the effort to realize quality pilkada. For all stages of organizing the elections, Bawaslu has issued various Bawaslu Regulations regarding supervision so that they become solid juridical guidelines for their implementation. Among them are Bawaslu Regulation Number 4 of 2020 concerning Supervision, Handling of Violations, and Dispute Resolution for the Election of Governors and Deputy Governors, Regents and Deputy Regents, as well as Mayors and Deputy Mayors [13] Simultaneously Continuing in Non-Natural Covid -19 Disaster Conditions.

Given the importance of overseeing the implementation of the pilkada and the very wide area of duties and powers of Bawaslu, it is very necessary to have public participation to support this. This is because it is impossible for all the burdens of government administration and development, including political development in the form of regional elections, to be fully borne by the election supervisory agency. Quantitatively, the number of members of this supervisory institution is not proportional to the number / area of areas, especially those whose geographic contours are not urban, and the election activity points that must be supervised.

With 3 or 5 commissioners at the district / city level, 3 at the sub-district level, 1 person at the village / kelurahan level, and 1 TPS supervisor, it is a challenge for the election supervisors to work more optimally. Likewise, the monitoring challenges that must be carried out at crucial stages, for example campaigns on social media. Related to this, the participation of the people will greatly assist the functional duties of the election supervisors at various levels. In other words, it can be said that one of the conditions for the successful implementation of the pilkada is community participation in all stages of the supervision of its implementation.

\section{Antimoney Politic Community Movement}

One important aspect of the implementation of election supervision is public reports of alleged violations of election regulations, whether committed by the administering apparatus, election participants, state officials, and members of the public in general. In other words, public participation is something that is very basic for the smooth running of elections, including pilkada. One form of participation is in providing accurate information to election supervisors regarding suspected irregularities in its implementation.

This is very important, because one of the indicators for implementing democratic elections according to Ramlan Surbakti and Didik Supriyanto is community participation [14]. With these various forms of public participation, it is a big contribution for Bawaslu and its staff to identify precisely each problem at all stages, especially those that have the potential in the form of money politics behavior. This needs to be underlined because one of the types of problems that always arise in the implementation of regional elections is money politics. This both in the short and long term, is very damaging to the joints of democratic life at the regional level.

Various pilkada stakeholders have the potential to be overshadowed by this practice, not only affecting the community, but also the organizers, pilkada participants and 
their campaign teams. According to Nuryanti, the regional head candidates seem to have difficulty enforcing justice in campaigning. Many restrictions are violated because of the strong influence of money politics [15]. This is one of the stains of local level democracy that seems very difficult to remove. In fact, one of the arguments for the elections to be diverted from indirectly to directly by the people as exercisers of sovereignty is to break the transactional political process in the people's representative institutions.

The facts still show that from time-to-time money politics is still a stain in the implementation of regional elections in various regions. Socio-psychologically, the thing that endangers the culture and life of democracy in the long term is when people who witness the existence of money politics perceive it as something that is commonplace. In fact, according to Sutrisno, in order to fight against money politics massively there must be a collective awareness that in fact the people are the most disadvantaged by the money politics practice scheme [16]. Efforts in this direction of course require optimism, confidence, continuity, consistency, and hard work from all election stakeholders.

Community awareness and pioneering are very important for the realization of quality pilkada through effective supervision. In this regard, one of the Bawaslu missions as stated in Bawaslu Regulation Number 6 of 2020 concerning the 2020-2024 Bawaslu Strategic Plan [17] is to improve the quality of innovative election prevention and supervision as well as community leadership in participatory supervision. The colossal and massive work of Bawaslu and its staff will be a great energy for the growth and development of the anti-money political movement.

There are still attitudes and behaviors that do not care and even consider it normal for various forms of election violations that are shown as members of the community, are facts that must be faced. There is a big challenge so that Bawaslu can multiply its institutional touch to each component of society. The attitude and behavior of some permissive members of society like this must really be stopped if all pilkada stakeholders still want the realization of a more qualified regional election.

\section{Collaboration for Quality of Pilkada}

In the implementation of national development, including in domestic political development in the form of regional administration and regional elections, it is impossible for all burdens to be borne by the government and election administrators. The smoothness and success of all pilkada policies and programs cannot be fully borne by the state and government institutions that are authoritatively assigned to various legislative regulations concerning the elections. In this regard, community participation in every stage of the pilkada becomes an important and strategic variable for the realization of quality pilkada.

In other words, collaboration between state / government actors who are involved as pilkada stakeholders, especially pilkada supervisors with non-state / government actors is a necessity and demand. According to Risal and Eka Pratiwi, one of the efforts that can be done is through cooperation with various parties, in order to increase public participation and the quality of elections [18]. The tough task of the election supervisory agency is to create a collective awareness that election administration is not solely the right and duty of stakeholders [19].

Rukun Tetangga (RT) according to Article 6 paragraph (1) Regulation of the Minister of Home Affairs Number 18 of 2018 concerning Village Community Institutions and Village Traditional Institutions [20] is one type of Village Community Institution. One of the duties of the Village Community Institution according to Article 4 paragraph (1) is to participate in development planning and implementation. One of its functions according to Article 5 letter e is to grow, develop and drive initiative, participation, self-help, and community cooperation. The working relationship between the Village Community Institution and the Village Government as stated in Article 12 paragraph (1) is a partnership. Thus, RT administrators are government partners at the lowest level to make the national development program successful, including the implementation of regional elections.

The implementation of quality regional elections is a form of domestic political development which is closely related to the hope of a more democratic regional government. Therefore, it is very clear that RT administrators can encourage community members in their area to actively provide information to pilkada supervisors at the village / kelurahan level and the TPS level about suspected irregularities in the implementation of the pilkada.

For example, in Bandung Regency, Regional Regulation Number 12 of 2007 concerning Social Institutions [21] has been issued. Article 23 letter d states that one of the functions of the Rukun Tetangga is the activator of self-help and community participation in the area. As a follow-up to the Regional Regulation, Regent Regulation Number 67 of 2011 concerning Rukun Tetangga (RT) and Rukun Warga (RW) [22] has been issued, which in Article 2 Paragraph (1) states that RT and RW are community organizations domiciled in villages and Kelurahan and become a partner of the Regional Government. Thus, it is clear that each RT that is a partner of the regional government at the lowest level is truly very large and decisive for the realization of a regional election that is free from money politics. This is partly because in general the RT administrators in each region are community leaders, opinion leaders, and community activists who are very effective in assisting each government program.

The anti-political money movement originating from and being supported by each RT is simultaneously synergistic in accordance with the duties of Bawaslu. Regency / city Bawaslu in Article 101 of Law Number 7 of 2017 [1], among others, has the task of preventing the practice of money politics. In this context, Bawaslu has the duties, among others, as stipulated in Article 102, namely increasing participation in election 
supervision. The effort to foster participation is certainly not an easy thing, because it will have a lot to do with various aspects, including the socio-cultural values of the local community.

Therefore, the declaration of an anti-political money movement that involves RT administrators in all Bawaslu working areas will really contribute to the quality of each stage of regional elections in general. For example, Article 33 of Bawaslu Regulation Number 10 of 2017 concerning Supervision of the Candidate Stages for the Election of Governors and Deputy Governors, Regents and Deputy Regents as well as Mayors and Deputy Mayors [23] has mandated that election supervisors involve the participation of related parties which is carried out, among others, in collaboration with community groups.

\section{CONCLUSION}

There has never been a single policy or program that was rolled out in the name of the public interest that will be smooth in its implementation. Pilkada is closely related to public interest, so that its supervisory function is of strategic value. Therefore, participatory supervision for quality pilkada involving all components of society, especially RT management is very important. Money politics in all its forms is a threat to democracy today and in the future. Collaboration between election supervisors and elements of society is a necessity. To that end, the belief, optimism, seriousness and continuity of the anti-political movement of money need to be cultivated. Only in this way money politics can be minimized and future regional elections will be of higher quality.

\section{REFERENCES}

[1] UU Nomor 7 Tahun 2017 about Pemilu.

[2] S. Haris, Dinamika Politik Pilkada Serentak. Malang: Pusat Penelitian Badan Keahlian DPR RI Jakarta bekerjasama dengan Inteligensia Intrans Publishing, 2017.

[3] T. Sudrajat, "Implementasi Kebijakan Institusionalisasi Nilai-Nila Demokrasi dan Makna Pemilu Melalui Pendidikan Kewarganegaraan Kepada Generasi Muda di Perguruan Tinggi,” Bdg. Maj. Ilm. Kopertis Wil IV No 5 Tahun XXVI, Desember 2013.

[4] S. Huntington, Gelombang Demokratisasi Ketiga (terjemahan). Jakarta: Pustaka Utama Grafiti, 1995.

[5] E. Michael, Public Policy: The Competitive Framework. South Melbourne: Oxford University Press, 2006.
[6] M. Budiardjo, Dasar-Dasar Ilmu Politik. Edisi Revisi. Jakarta: PT. Gramedia Pustaka Utama, 2008

[7] D. Dahl, Analisis Politik Modern. Bumi Aksara, 1994.

[8] M. Budiardjo, Demokrasi di Indonesia. Demokrasi Parlementer, Dan Demokrasi Pancasila. Jakarta: PT. Gramedia Pustaka Utama, 1999.

[9] J. Blondel, Comparative Government: An Introduction. Second Edition. London: Prentice Hall/Harvester Wheatsheap., 1995.

[10] A. Ball, Modern Politics and Government. The Macmillan Press, Ltd., 1975.

[11] Peraturan Pemerintah Pengganti Undang-Undang Republik Indonesia Nomor 1 Tahun 2014 Tentang Pemilihan Gubernur, Bupati, Dan Walikota.

[12] S.P. Siagian, Filsafat Administrasi. Edisi Revisi. Jakarta: Bumi Aksara, 2008.

[13] Peraturan Bawaslu Nomor 4 Tahun 2020 tentang Pengawasan, Penanganan Pelanggaran, dan Penyelesaian Sengketa Pemilihan Gubernur dan Wakil Gubernur, Bupati dan Wakil Bupati, serta Walikota dan Wakil Walikota Serentak Lanjutan Dalam Kondisi Bencana Nonalam Covid -19.

[14] N.Y. Simanjuntak, "Pemantauan Dalam Proses Penyelenggaraan Pemilu," Badan Pengawas Pemilihan Umum Repub. Indones., vol. 3, no. 3, 2017.

[15] S. Nuryanti, "Intervensi Penyelenggaraan Pemilukada: Regulasi, Sumberdaya dan Eksekusi," J. Ilmu Sos. Dan Ilmu Polit., vol. 19, no. 2, pp. 125-140, Nov. 2015, doi: 10.22146/jsp.10849.

[16] C. Sutrisno, "Partisipasi Warganegara dalam Pilkada," J. Pancasila Dan Kewarganegaraan, vol. 2, no. 2, 2017.

[17] Peraturan Bawaslu Nomor 6 Tahun 2020 tentang Rencana Strategis Bawaslu Tahun 2020-2024.

[18] S. Risal and E. Pratiwi, "PARTISIPASI POLITIK MASYARAKAT PERBATASAN NEGARA DALAM PILKADA SERENTAK D KABUPATEN MALINAU," DIA J. Ilm. Adm. Publik, vol. 17, no. 2, Art. no. 2, Dec. 2019, doi: 10.30996/dia.v17i2.3010.

[19] Y. Murafer, "Peningkatan Pengawasan Partisipatif Oleh Panwaslu Kota Jayapura Dalam Pemilihan Gubernur Dan Wakil Gubernur Provinsi Papua Tahun 2018 Di Kota Jayapura,” J. Polit. Pemerintah., vol. 2, no. 2, Art. no. 2, 2018.

[20] Peraturan Menteri Dalam Negeri Nomor 18 Tahun 2018 tentang Lembaga Kemasyarakatan Desa dan Lembaga Adat Desa.

[21] Peraturan Daerah Kabupaten Bandung Nomor 12 Tahun 2007 tentang Lembaga Kemasyarakatan.

[22] Peraturan Bupati Bandung Nomor 67 Tahun 2011 tentang Rukun Tetangga (RT) dan Rukun Warga (RW).

[23] Peraturan Bawaslu Nomor 10 Tahun 2017 tentang Pengawasan Tahapan Pencalonan Pemilihan Gubernur dan Wakil Gubernur, Bupati dan Wakil Bupati serta Walikota dan Wakil Walikota. 